\title{
Solidarity statement by academics attending MMFF
}

Delegates to the Melanesia Media Freedom Forum express

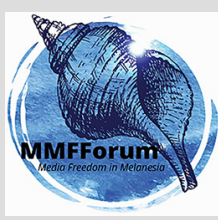
their solidarity with media workers in Melanesia in their struggle for freedom of expression, security, and professional recognition.

Delegates note the words of Secretary-General of the Pacific Islands Forum Dame Meg Taylor who told the Asia Lecture at Griffith University, Brisbane, on 11 November 2019: 'We live in unprecedented times of change which will test our abilities to respond.'

Dame Meg outlined a range of threats facing the Pacific, including growing militarism and the fragility of national boundaries and natural resources. However, she said climate change was the greatest threat facing the wansolwara.

It is against this background that the Melanesian journalists attending the conference outlined their experiences and concerns.

Melanesian delegates spoke of a litany of difficult circumstances they faced. These included beatings, torture and murder and torture by Indonesian security officials in West Papua and the threats made to media workers in other countries.

The internet was threatening media consumers because it was often used to spread distorted versions of events and outright lies.

Several delegates said they were facing the challenge of multiple news platforms by improving their own performance and engaging with online audiences. However, they faced problems with online content produced by people who claimed they were journalists, but who had no standing in the profession.

There were strong concerns about the need to distinguish professional journalists from other content producers.

Delegates expressed strong concerns about issues of human rights, violence, and freedom of expression.

They also expressed concerns about the effect of stifling legislation that had the power to impose heavy fines and prison sentences on journalists.

We also note the comments of Fred Wesley, editor-in-chief of The Fiji Times who said, after relating his long-and successful-legal battle with the Fiji government: 'The truth needs to be told every day.'

We also note the words of encouragement given to Melanesian journalists by the man regarded by many as the journalist emeritus of Pacific reporting, Sean Dorney. Dorney said that in the current difficult circumstances, members of the media needed to support each other. 
'We have to keep up the good fight and keep in touch with each other,' Dorney said.

He told delegates the work of the media was essential in keeping 'the fire burning'.

'I have nothing but admiration for anybody working in the media in the region.'

Therefore, consistent with the United Nations Declaration of Human Rights, particularly Article 19 which protects the right to express opinions and communicate information and ideas in different ways; and in line with the United Nations 2030 development goals, particularly those designed to strengthen peace, justice and strong institutions; climate action; reduce inequalities; and gender equality; delegates to the forum call for journalists working in Melanesia and across the Pacific, to be guaranteed the following basic rights as professional communicators:

- $\quad$ Freedom of expression

- Freedom from physical abuse, threats, or intimidation in pursuit of their work

- Recognition of their status as professional communicators

- Security of digital communication

- Equality for all media workers in terms of their professional standing, regardless of gender

- $\quad$ Recognition and protection under law of these rights

\section{Dr Philip Cass}

Acting Editor of Pacific Journalism Review

Brisbane

12 November 2019 